Dept. of Veterin. Anat., Coll. of Agricult., Univ. of Osaka Prefecture,

Sakai, Osaka (Director: Prof. H. MORITA).

\title{
Fuchsinophilia in the LEYDIG Cells of the Rat Testis.
}

\author{
大黒鼠婞丸 Leydig 細胞内のフクンン好性物質.
}

\section{Shoji YAMAUCHI 山内 昭 二.}

(Received December 2, 1955.)

\section{Materials and Methods.}

Nineteen adult and eleven premature rats of WISTAR strain were used in this work. Testes were removed immediately after blocking head. Fresh tissue of the testis was cut into pieces, then fixed in BOUIN, ZENKER-formol $(4: 1)$ and Sublimate-formol $(9: 1)$ solution respectively. Thin paraffin sections were obtained according to the routine method.

The trichrome stain of MASSON and ponceau-fuchsin stain were used to reveal the cytoplasmic feature of interstitial cells. As an aid to the study of general histology, sections were prepared with the MALLORYHEIDENHAIN's Azan (containing methyl green instead of aniline blue) stain. Balsam mounted preparations after rapid dehydration were available for microscopic investigation for more than a year.

Of the fixatives stated above, ZENKER-formol gave generally satisfactory results. Degranulation as well as granulation of LEYDIG cells was best observed with the ponceau-fuchsin stain and the preparation with the Azan stain proved most suitable for the demonstration of the reticular framework in the intertubular space.

\section{Results and Discussions.}

Minute granules were located homogeneously in the compact cytoplasm of young LEYDIG cells. These cells were densely greenish granular by the Azan stain.

HOOKER (1944, 1948) stated that the development of LEYDIG cell consists of two phases. The one is the metamorphosis of the indifferential cell into the cell of LEYDIG and the other is the secretion of mature LEYDIG cell. In a rat testis, the author $(1954,1955)$ observed the life history of LEYDIG cells and described as follows: the cytoplasmic accumulation as well as the changes in a nuclear pattern were principal in a metamorphosis and mature LEYDIG cells exhibited a degranulation accompanied by vacuolation and succeeding disintegration.

With the progress in maturation of the LEYDIG cells, minute granules became coarser in size and yellowish in color. Lipoid droplets 
have appeared in a LEYDIG cell when the yellowish granules occupied the entire cytoplasm.

The next change in the LEYDIG cell was degranulation. Preceding this change the cytoplasm exhibited vacuolation in the peripheral zone. Thereafter vacuoles became increasingly numerous towards the central portion till the cells inclined to disintegration.

The reticulum which forms the connective tissue framework in the intertubular spaces in a testis becomes more prominent with increasing maturation of the rat. The framework lies along the vascular channels and extend among the cells separating them into nests or clumps. Therefore many coarser granules were usually located along the framework.
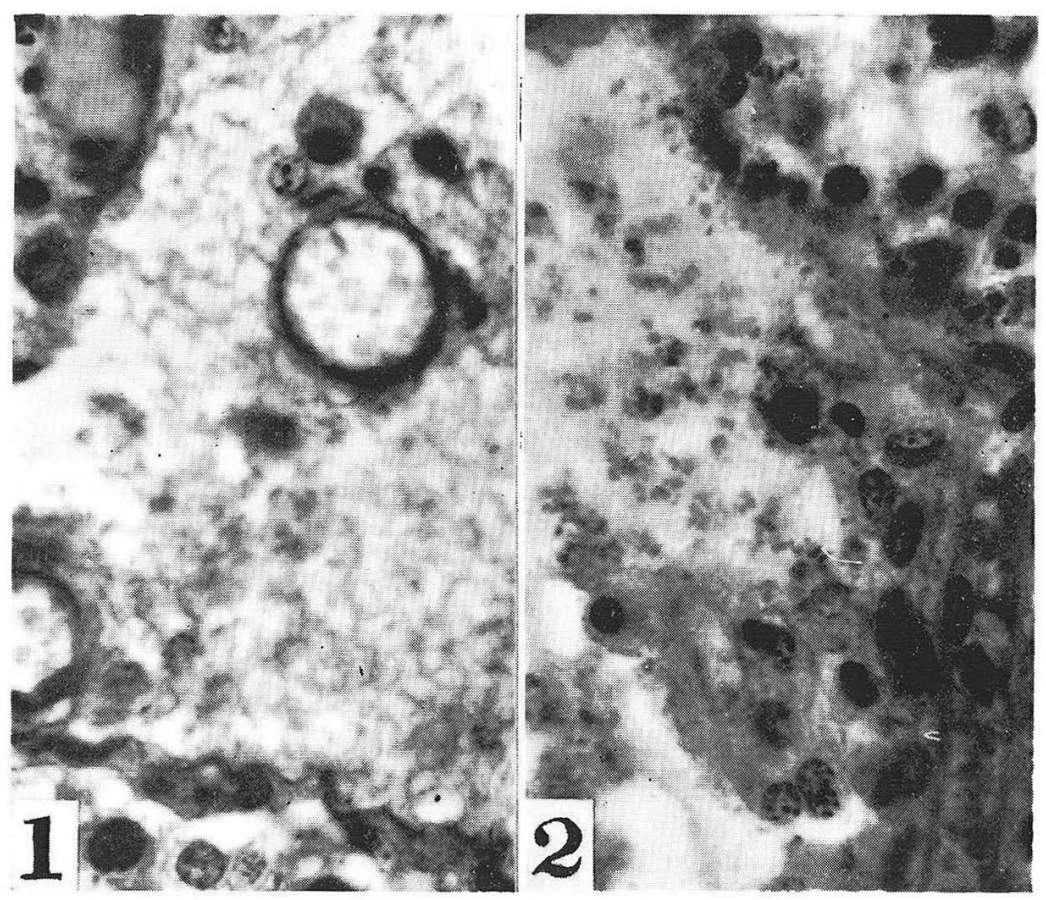

Fig. 1. The reticular framework spreads throughout the intertubular space in a testis of the adult rat. Many cells are being disintegrated. Azan stain. $\times 600$.

Fig. 2. A portion of the intertubular space in which many LEYDIG cells are being degranulated. Coarser fuchsinophilic granules are scattered throughout the space. Disintegrated cells with pycnotic nuclei are numerous. Ponceaufuchsin stain. $\times 600$.

The brilliant red granules stained by ponceau-fuchsin seem to be the same granules which take yellowish color with the Azan stain. 
Both metamorphosis and degranulation are always seen in a testis of adult rat, meanwhile in a rat up to the age of 1 month the intertubular tissue consists of fibroblasts and connective tissue fibers.

At approximately one month of age, the metamorphosis from indifferential cells into LEYDIG cells had appeared first in a few of the large cells. Round nuclei with light chromatin structures became numerous among the cells with spindle-formed, denser nuclei. At the same time there was active growth of former cells which show the loss of processes. Simultaneously with their growth most of the slightly enlarged cells acquired a cytoplasmic granulation.

With the progress in maturation of the LEYDIG cells, the coarser granules increased in number and thereafter occupied the entire cytoplasm. The time of this histological change in the intertubular features corresponds to the puberty of the individual animal.

Degranulation of mature LEYDIG cells have appeared in the intertubular space previous to the appearance of mature spermatozoa in a tubule.

LYNCH and SCOTT (1951, 1952) stated that in the human testis, the maturation of interstitial tissue precedes the spermiomorphosis, in the meanwhile in some strain of rats no lipids were seen in the interstitial tissue of testis.

In a bull testis, HOOKER (1944) stated that the appearance of mature spermatozoa have appeared earlier than the maturation of intertubular tissue. According to the report on monkey testes by VAN WAGENEN and SIMPSON (1954), mature LEYDIG cells have appeared prior to the maturation of the individual animal.

In this study, fuchsinophilic granulation and degranulation in the LEYDIG cells became more intense in the testis after the puberty of animal. In a histochemical study on various mammalian testes POLLOCK (1942) described that the steroid substances are confined to the interstitial cells and are not detectable anywhere else in the gland.

If the fuchsinophilia in the LEYDIG cells which is described in this report, may represent the male hormone as suggested by ZINSSER and ZINSSER (1952), the relation of the testicular endocrine function with the maturation of animal is to be considered with more critical interests.

\section{Summary.}

The investigation of rat testes was conducted to ascertain whether the testicular endocrine function bears any relation to the maturation of animal from the view point of morphological aspects. The ponceau-fuchsin stain was employed and the results were compared with those of Azan stain made for general histology. 
Interstitial cells are distinguishable as LEYDIG cells at approximately 1 month of age which corresponds to the puberty of individual animal. From this date onward mature LEYDIG cells show degranulation as well as the peripheral vacuolation. The granular interstitial cells differentiated from indifferential cells. Transformation into the LEYDIG cell involves nuclear changes as well as the acquisition of much cytoplasm which underwent an apparent sequence of modification. The disintegration of LEYDIG cells appeared first in a few of the large cells in the animals prior to the appearance of mature spermatozoa in a tubule.

In an adult rat testis, various stages in the disintegration of LEYDIG cells were seen in the intertubular space, where a well-developed reticular framework is seen spread throughout the entire space. Whole cytoplasm of mature LEYDIG cells are filled with fuchsinophilic granules, on the other hand no fuchsinophilic, granular cells were seen in an immature rat testis.

Thus the fuchsinophilic granules are seen abundantly around the degranulating cells and in the framework. Fuchsinophilia in the LEYDIG cells may be considered to be in close relation with the male hormone substance.

Acknowledgements.

The author wishes to express his sincere gratitude Dr. H. MORITA, for the helpful suggestions and to Dr. S. NISHIDA, professor of the Tokyo University for the instruction of this work.

\section{内容自 抄。}

睪丸間質組織が個体の成熟過程飞於いて如何なる関連性を示すかを検索 する目的で, 大黒鼠睪丸とついて形態学的観点から研究し考察を加えた。 成熟19匹，未成熟11匹の Wistar 系大黒鼠を使用した。通常の染色標本及 び ponceau fuchsin 染色標本を観察し, 間細胞の形態と意義とついて次の 如き結論を得た。

紊丸間細胞が典型的な分泌性 Leydig 細胞として明らかと識別出来るの は凡そ 1 月令の時で，これは個体の春機発動期と相当する様と思われる. 此の時を境にして Leydig 細胞は周辺部飞空胞を示すのと同時飞顆粒放出 を行なう様になって来る．未分化細胞から顆粒性間細胞への移行は細胞質 が増大して行くのと同時と核型とも変化が起り，両者は併行して連続的な 過程を径由する。

精細管内に精子発生が出現する以前に, 少数の大形間細胞は細胞崩壞を 示す，従って成熟個体の辠丸間質と形態学的には区別することが出来ない 間質組織が精子発生前の未成熟個体輧丸に見られる. 又此の時期の前後飞 
於いて辠丸間細胞の増殖が最も多数出現し, 未成熟及び成熟個体の殬丸間 質飞於ける大部分の間細胞は未分化細胞からの变態飞由来するものと思わ れる。

成熟個体の箤丸間質とは良く発達した結合織繊維の網工が精細管間の部 分飞伸張し，此処飞は多数の崩壊過程を示す Leydig 細胞が見られる. 成 熟 Leydig 細胞の全細胞質にはフクンン好性顆粒が充満している. 一方未 成熟個体の睪丸間質組織とは此の様なフクンン好性且つ顆粒性細胞は全く 見られない。此のフクンン好性顆粒は azan 染色標本によって得られた orange G 好性顆粒と形態的飞区別する事が出来ず，その分布及び態度か ら考えて同じ物質と考えられる。

上述のフクンン好性顆粒は成熟間細胞内飞充満している他に, 顆粒放出 を行なっている細胞及び崩壞を起している細胞の周囲等飞も多数見られ， 且つこれらの細胞を包含している結合織繊維の稠密な網眼内と大量飞散在 している。個体の成熟過程て於ける結果と併せて，このフクンン好性物質 が androgen 様物質を現わすものと考えるならば性現象の形態学的解明に 興味ある知見となる様飞思われる。

\section{References.}

Hooker, C. W. : The postnatal history and function of the interstitial cells of the testis of the bull. Amer. J. Anat. 74 (1944). P. 1. - The biology of the interstitial cells of the testis. Recent Progress in Hormone Research. 3 (1948). P. 173. - Lynch, K. M. Jr. a. W. W. Scott : Lipid distribution in the Sertoli cell and Leydig cell of the rat testis as related to experimental alterations of the pituitary-gonad system. Endocrinol. 49 (1951). P. 8. - The Sertoli cell as related to age of man and experimental alteration of the pituitarygonad axis in the animal. With consideration of its role in spermatogenesis. Fertility and Sterility. 3 (1952). P. 35. - Pollock, W. F.: Histochemical studies of the interstitial cells of the testis. Anat. Rec. 84 (1942). P. 23. Van Wagenen, G. a. M. E. Simpson : Testicular development in the rehsus monkey. Anat. Rec. 118 (1954). P. 231. - Yamauchi, S.: On a morphology of testicular interstitial cells (Jap.) Kagaku. 24 (1954). P. 368. - Histo- and endocrinological studies on the interstitial cells of rat testes. I. Postnatal development of interstitial tissue in the testis. (Jap.) Kaibo Z. (Acta anat. nipp.) 30 (1955). P. 377. - Zinsser, A. D. a. H. H. Zinsser : Fuchsinophilia in the adrenal cortex. Arch. Path. 51 (1952). P. 393. 